\title{
Unhappy pills?
}

\section{The trials and tribulations of antidepressant drugs.}

\section{Medicines Out of Control: Antidepressants and the Conspiracy of Goodwill \\ by Charles Medawar \& Anita Hardon Aksant/Transaction: 2004. 258 pp. $\mathfrak{1} 19.25 / \$ 34.95$ \\ Let Them Eat Prozac: The Unhealthy Relationship between the Pharmaceutical Industry and Depression \\ by David Healy \\ New York University Press: 2004. 340 pp. $\$ 29.95$ \\ John Cornwell}

In 1994 , as lawyers for the pharmaceutical giant Eli Lilly were beginning a historic legal defence of the antidepressant Prozac, researchers were descending from all over the world on Miami Beach, Florida, for the twenty-fourth annual meeting of the American Society for Neuroscience. Among the 10,000 posters on show at the meeting, hundreds displayed research on the serotonin system, with scores of these devoted to fluoxetine hydrochloride, better known as Prozac. One poster showed the work of Ray Fuller of Eli Lilly, who invented Prozac. But Fuller wasn't there. He was in Louisville, Kentucky, giving evidence in the Eli Lilly Prozac trial. It involved a man called Joseph Wesbecker, accused of shooting 20 people in his workplace with an AK47 after being on Prozac for just over a month. Eight of his victims died and he committed suicide.

This was the mid-point of the Decade of the Brain. To attend the annual neurosciences meeting was to submit oneself to a tidal wave of varied research programmes, from genetics to neuronal degeneration, from memory to neurotransmitters, from pharmacology to the visual cortex, and from brain imaging to new pain therapies. Nowhere in the world was there such a large and optimistic gathering of scientists convinced that they were about the change the world.

The decision of the House and Senate of the United States to designate the 1990s as the Decade of the Brain was not just scientific optimism, however; it was the result of lobbying by the pharmaceutical industry. The carrot had been budgetary: an estimate that some $\$ 350$ billion was being lost to the US economy each year through brainrelated ills, including depression, Alzheimer's and the consequences of aggressive behaviour. The promise of major social and medical amelioration was driving and directing the rapid expansion of investment and funding. These two volumes, Medicines Out of

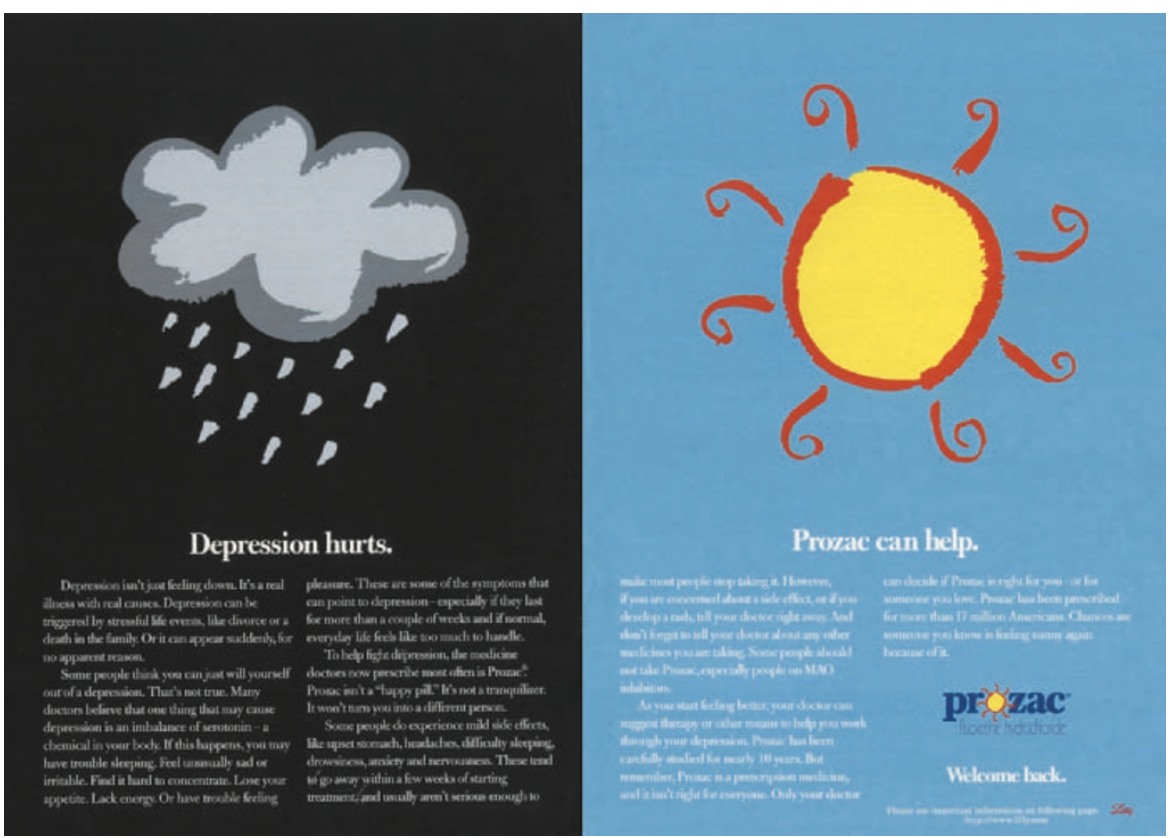

Blue skies - or just blues? Prozac seemed like a miracle treatment for depression, but after a blaze of publicity in the media (below), things soon started to turn sour for its manufacturer, Eli Lilly.

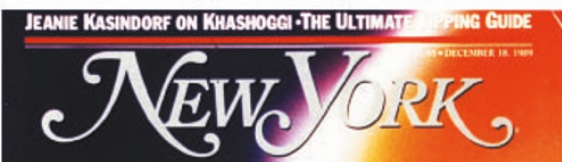

A New

Wonder Drug for

Depression

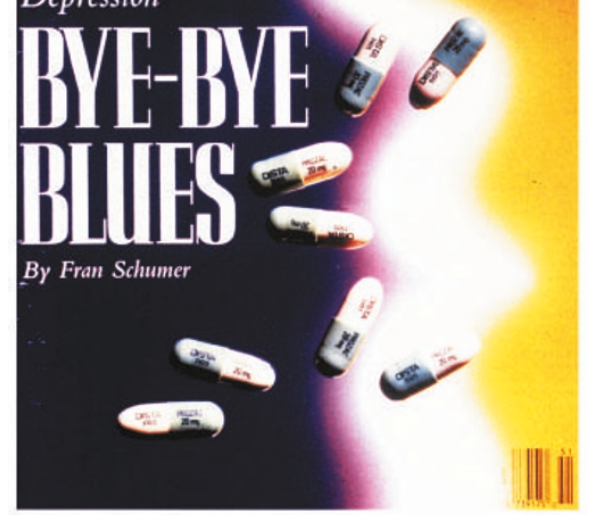

Control and Let Them Eat Prozac, measure the failure of the Decade of the Brain to deliver the goods in the crucial arena of new antidepressants.

A chief benefit of new psychopharmacology was the hope that designer medications would bring an end to dependence problems. In theory, matching a chemical product to known receptor sites would avoid the unwanted side-effects of older drugs, whose discovery was mainly serendipitous. Medicines Out of Control tells the story of a looming crisis in the side-effect of depen- dency on new drugs. The turning point signalled by the authors was 25 June 2003, when GlaxoSmithKline published an amendment to the prescribing instructions for the antidepressant Seroxat (Paxil). The company revised its earlier estimate of the risk of withdrawal reactions from $0.2 \%$ to $25 \%$. In setting the scene for their thesis, the authors tell us that the prodigious increase revealed that "science was catching up with common sense".

One of the central issues of the book is the mismatch between the industry's clinicaltrial systems and the anecdotal evidence of patients. The authors argue that evidence from users began to flow in earnest in the mid-1990s with the growth of the Internet. The web "had begun to change history" as users of antidepressants began to compare notes and exchange ideas on an unprecedented scale. The authors' conclusion - that the community created by new information technology should be adapted and adopted by the medical profession, especially in the case of drugs for the mind - seems not only sensible but obvious. Will the pharmaceutical industry respond? Is it in their interest to do so?

Which brings us to David Healy's Let Them Eat Prozac, an even more sombre story of psychopharmaceutical folk and patients. For beyond the dangers of dependence are the alleged dangers of aggression and selfharm, particularly in the case of the selective serotonin reuptake inhibitors (SSRIs), of which the most famous is Prozac. Healy, 
who is a psychiatrist and prolific author of books and articles on psychopharmacology, used to prescribe Prozac happily. Like many clinicians, he was impressed: just one pill a day to bring a patient out of a wide variety of depressive complaints. Only with time did he realize that his patients were complaining of agitation and suicidal ideation. Then came that landmark trial in Louisville involving Wesbecker and Eli Lilly. The many expert witnesses revealed the alarming relationship between new brain science and the commercial goals and shortcuts of the pharmaceutical industry.

Healy's tale is complex and detailed, bringing together a huge amount of clinicaltrial data and case histories. Ultimately, the book is about science, society and the power and misuse of commercial promotion. "We are facing a future of real biomedical developments," he concedes, but these are taking place in a world "in which corporate capacities to colonize the consciousness of citizens, physicians, regulators, and others outstrip their capacities to bring real benefits on stream". His investigation is impressive but is, in the final analysis, depressing, for he has no ready answers for the ills he describes. One can only hope that the benefits of commercially based psychopharmacology ultimately outstrip the catastrophes - but Healy is not prepared to concede such a conclusion. Perhaps our best hope is for vigilant and painstaking whistle-blowers, of which the authors of these two studies are formidable examples.

John Cornwell is director of the Science and Human Dimension Project, Jesus College, and is in the Department of History and Philosophy of Science, University of Cambridge, Cambridge CB2 3RH, UK. He is the author of The Power to Harm: Mind, Murder and Drugs on Trial.

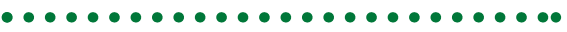 The King of Siluria's journey}

Murchison's Wanderings in Russia edited by Michael Collie \& John Diemer British Geological Survey: 2004. 474 pp. $£ 40$ http://www.bgs.ac.uk/bookshop

\section{Ralph O'Connor}

If you had been rowing across the Volga near Kazan, western Russia, in May 1841, you might have been startled by the sound of raucous singing:

\section{Ah, the red sandstone! How bored am I! \\ I'd very well pay a thousand louis \\ Never again in my life to see \\ The new red sandstone of Tartary!}

The singer (and composer) was Roderick Murchison, the greatest practical geologist of

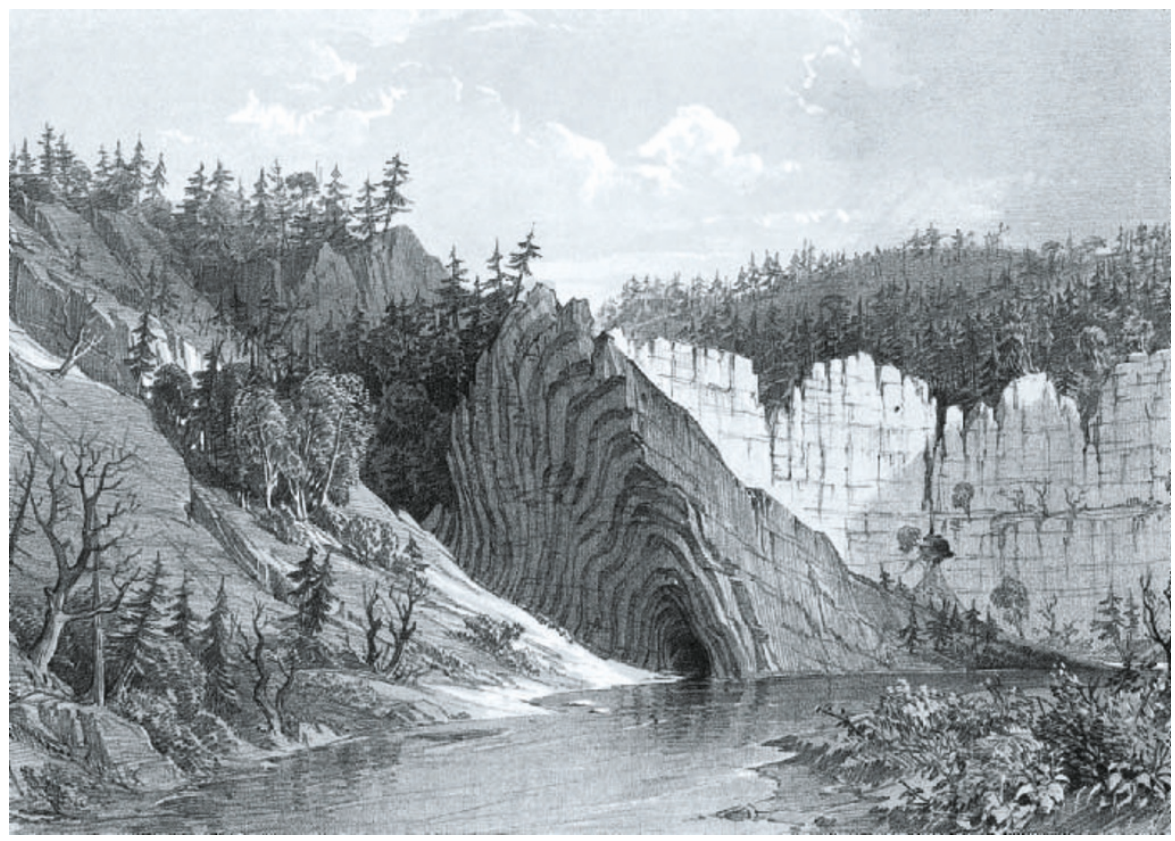

Geologist Roderick Murchison studied the gorge of the River Chusovaya on his travels through Russia.

his day and a key player in Queen Victoria's empire. In their search for mineral resources, Britons of the time were organizing and stamping their authority on landscapes past and present, naming periods such as the Cambrian, Silurian and Devonian after British localities and peoples. Strata had become the central concern of geology, not so much for telling the story of life - though this was a good way of selling books - as for mapping the positions of rocks and correlating them across the globe.

Murchison had become famous in the 1830 s as the man who made sense of the earliest Palaeozoic strata in the Welsh borders. He now meant to give his 'Silurian system' a global reach. In 1840 and 1841, Murchison and three colleagues sped across the Russian plains, covering thousands of miles and adding new territories both to his geological empire and to the Tsar's coal reserves. Such an exhausting and exhaustive campaign naturally had its dull moments, hence the song quoted above.

His findings were written up in the hefty Geology of Russia (1845), and the honours he had craved since he abandoned his military career at last poured in - he was hailed as the 'King of Siluria' and as the Copernicus of the age. But intellectual ossification was quick to follow: from this point on he knew he was right, and cultivated the impenetrable formality of the retired general.

Murchison also wrote up his travels in a less formal manner. His journal, Wanderings in Russia, provides a continuous narrative of his 1840 and 1841 expeditions, and is here published for the first time. This handsomely produced book should be welcomed by historians and geologists alike. It is full of fascinating anecdotes about local customs, manners and rocks from St Petersburg to the
Urals. Social commentary was not Murchison's forte, but in his clipped way he provides a rich mine of specific information about the land through which he was travelling .

As a travel writer, Murchison cannot compare with his fellow geologist and Scotsman, Hugh Miller, whose marvellous Hebridean travelogue The Cruise of the Betsey (1845-49) has also recently been reprinted (see Nature 426, 19; 2003). Where Miller has the novelist's gift for character and incident, Murchison just rambles on. But once you get used to the amoebic shape of the narrative and its periodic outbursts of self-congratulation, Wanderings in Russia is an enjoyable read, full of humour as well as picturesque description. If is, of course, highly revealing of Murchison's own attitudes, including his affection for the Russians at a time when British 'Russophobia' was on the rise.

Michael Collie and John Diemer have done a splendid job of editing this massive text, helpfully splitting it into short sections and inserting a running commentary, with detailed maps and notes. The full-size colour reproduction of the Geology of Russia's enormous geological map, tucked conveniently into a pocket at the back, deserves special praise. My only reservations concern the rather short introduction, which, despite many useful insights, is too involved in minutiae to give the general reader much of a foothold. Too much time is spent worrying about Murchison's political incorrectness, and the editors refuse point-blank to discuss his "supposed imperialism" (as if that were ever in doubt), although this aspect of his career has recently excited more interest than any other.

The bibliography has some striking omissions, in particular James A. Secord's 